\title{
Jacob Sasportas and Problems of Discipline in the Ets Haim Yeshiva
}

\author{
Yaacob Dweck
}

Jacob Sasportas (c. 1610-1698), is known as the primary opponent and critic of Sabbetai Zevi, the Jewish Messiah of the mid-seventeenth century. In his Hebrew masterpiece, Zizath Novel Zvi (The Fading Flower of Zvi), he composed a chronicle and study of the Sabbatian messianic movement as it was occurring in the middle of the 166 os. $^{1}$ This paper focuses on another aspect of Sasportas's long and colorful life: his relationship with the Ets Haim yeshiva in Amsterdam. In doing so, it picks up where Matt Goldish left off in his study of Sasportas and the conversos. ${ }^{2}$ As Goldish showed, Sasportas's relations with his co-religionists in the Western Sephardic diaspora were often fraught. In the case studied by Goldish, a responsum from Ohel Ya'akov on returning conversos and the rites of penitence, Sasportas was at odds with the Portuguese Jewish community in London, a city in which he lived for slightly more than a year in 1664 and 1665 . Sasportas had fought bitterly with the parnassim in London as well, as Isaiah Tishby demonstrated in $1988 .^{3}$ Decades earlier, Tishby had examined the conflict between Sasportas and the parnassim in Livorno. ${ }^{4}$ Both articles had resulted from his work on Sasportas in the preparation of his edition of Zizath Novel Zvi, a monument of scholarship that remains the fundamental point of departure for any and all work on Sasportas.

This article concentrates on a different responsum within Ohel Ya'akov, Sasportas's collected responsa printed posthumously in 1737, and a different community in the Western Sephardic diaspora, Amsterdam itself. ${ }^{5}$ Sasportas

1 Jacob Sasportas, Zizath Novel Zvi, ed. Isaiah Tishby (Jerusalem: Mossad Bialik, 1954).

2 Matt Goldish, "Hakham Jacob Sasportas and the Former Conversos," Studia Rosenthaliana 44 (2012): 149-72.

3 "New Information on the 'Converso' Community in London According to the Letters of Sasportas from 1664/1665," [Hebrew] in Galut Ahar Golah: Mehkarim be-Toldot Am Yisrael Mugashim le-Professor Haim Beinart li-Melot Lo Shivim Shanah, ed. Aharon Mirsky et al. (Jerusalem: Ben Zvi Institute, 1988), 470-96.

4 "Letters by Rabbi Jacob Sasportas against the Parnassim of Livorno from 1681," [Hebrew] Kovets Al Yad (4) 1946: 143-60.

5 Jacob Sasportas, Ohel Ya'akov, ed. David Meldola (Hertz Levi Rofe: Amsterdam, 1737).

(C) YAACOB DWECK, 2019 | DOI:10.1163/9789004392489_015

This is an open access chapter distributed under the terms of the prevailing CC-BY-NC License at the time of publication. 
lived in Amsterdam for extended periods of time between his arrival from Tlemcen, North Africa, to Northern Europe in the late 1640 os or early 165 os and his death half a century later in 1698. Indeed, more than any other city he lived in over the final five decades of his life-Salé, London, Hamburg, The Hague, and Livorno-Amsterdam was his most frequent place of residence. It was in Amsterdam that he first arrived around the middle of the century. It was there that his family joined him somewhat later, when the community paid the ransom to redeem them from their captivity. ${ }^{6}$ And it was in Amsterdam in the 1650 s where he found work as a corrector in the print shop of Menasseh ben Israel and patronage from the Mercado family.

Between 1658 and 1675 , a period of nearly two decades, Sasportas lived in a number of other places. Unlike so many of the other wandering rabbis of the seventeenth century, Sasportas actually returned to the region from which he came. Between 1658 and 1663 , Sasportas lived in North Africa. This time, though, he was in Salé on the Atlantic coast, rather than Oran and Tlemcen, cities on or near the Mediterranean coast. During this period, however, his connections with the Jews of Amsterdam did not cease. A notarial deed in the city archives in Amsterdam indicates that Sasportas continued to engage with the Mercado family in Amsterdam while he was in Salé. ${ }^{7}$ When he fled a famine in Salé in 1664, Sasportas made his way to London where he served for slightly over a year as rabbi to the fledgling Portuguese Jewish community. In the summer of 1665 he fled the plague in London and ended up in Hamburg, where he lived for the next seven years and where he wrote Zizath Novel Zvi. Yet, even while he was living in Hamburg, he continued to receive charity from the Portuguese Jews of Amsterdam. ${ }^{8}$ In Zizath Novel Zvi itself, he recounts a journey he made from Hamburg to Amsterdam in the midst of the messianic frenzy to collect his son Samuel who had managed to escape from London only after his father. ${ }^{9}$ Sasportas returned to Amsterdam in the early 167os, and, after

6 Stadsarchief Amsterdam [hereafter SAA], 334 no. 19, p. 342. On the nature of this source, see Yosef Kaplan, "The Social Function of the Herem," in An Alternative Path to Modernity: The Sephardi Diaspora in Western Europe (Leiden: Brill, 2000), 110. On the ransom of the Sasportas family, see the note by Fuks and Fuks-Mansfeld in David Franco Mendes, Memorias do estabelecimento e progresso dos Judeos Portuguezes e Espanhoes nesta famosa citade de Amsterdam, ed. L. Fuks and R.G. Fuks-Mansfeld, Studia Rosenthaliana 9, no. 2 (1975): 16o, n. 122.

7 SAA 5075, no. 2205, Not. A. Lock, 23 September 1658, fol. 466.

8 SAA 334, no. 174, p. 733, 21 Tebet 5426. "A mandej pagar ao H. Sasportas em Hamb." I owe this reference to the kindness of Dr. Tirtsah Levie Bernfeld. On the phenomenon of people who had left Amsterdam receiving poor relief abroad, see Tirtsah Levie Bernfeld, Poverty and Welfare among the Portuguese Jews in Early Modern Amsterdam (Portland, OR: The Littman Library of Jewish Civilization, 2012), 89.

9 Sasportas, Zizath Novel Zvi, 70. 
a brief stint in Livorno between 1678 and 1680, he returned to Amsterdam in the fall of 1680 , where he lived for the final eighteen years of his life.

It this last period of his life that is the focus of this paper. On the face of it, this was a period in Sasportas's life when he had finally arrived, so-to-speak. His name appears regularly in the scheduled payments of rabbinic personnel in the archives of the Portuguese Jewish Community in Amsterdam. In the Livro Longo he appears as one who regularly received a salary for his teaching in the 1680 os and 169os, when he had a position as a teacher in the Ets Haim yeshiva. He began to issue haskamot to a plethora of Hebrew books as well as some Yiddish books that appeared at the Hebrew presses in Amsterdam in the 1680 s and 1690 s. Of his four sons who lived well into adulthood-Samuel, Moseh, Isaac, and Abraham - three lived in Amsterdam. Abraham was married with children. Three of Sasportas's four living daughters were married and lived in Amsterdam as well. His son Samuel's death in London in 1692 had left him a relatively wealthy man. ${ }^{10}$ In 1693 , after having served for nearly a decade as a teacher in Ets Haim and after having lived in Amsterdam on and off for forty-five years, he became the Hakham of the Portuguese community. He had finally acquired the authority and the respect that he had craved for so long. From the vantage point offered by Sasportas's career, the rabbinate after Sabbatianism was looking quite robust.

All was not quite as it seemed. From a report in the travel diaries of Hayim Yosef David Azulai first highlighted by S.Z. Havlin, it emerges that Sasportas was not the community's first choice to become chief rabbi upon the death of Hakham Isaac Aboab da Fonseca in $1693 .{ }^{11}$ Only after Hezekiah de Silva, a Talmudic scholar who was in his early thirties had turned the job down, did the communal elders turn to the eighty-three-year-old Sasportas. To add to this, one can point to a striking and deafening silence. Sasportas was an intellectual who was keenly aware of the power of the printed word and who nursed considerable ambitions as an author. Yet throughout this entire period of his life, very few of his own writings appeared in print. While the polemical nature of Zizath Novel Zvi may go a considerable way to explaining his reticence to print it, neither his responsa nor a now lost commentary he wrote on the Mishnah appeared in print during this interval, a period when he still had considerable

10 London, PRO, Prob/11/411, Samuelis Saportas.

11 Sefer Ma'agal Tov ha-Shalem, ed. Aron Freimann (Jerusalem: Mekize Nirdamim, 1934), 157. As cited by S.Z. Havlin, "On the History of the Talmudic Academies in Jerusalem and Their Scholars at the End of the Seventeenth and Early Eighteenth Centuries," [Hebrew] Shalem 2 (1976): 146-47. 
connections to the world of Hebrew books in Amsterdam as one who issued approbations. ${ }^{12}$

With all of this in mind, the incident recounted in responsum number 60 in Ohel Ya'akov appears to demonstrate how difficult Sasportas found his job in Ets Haim at certain points. ${ }^{13}$ Responsum number 60 appears toward the end of Ohel Ya'akov. It does not contain a date, but internal evidence suggests it was written at some point between Sasportas's return from Livorno in 1680 and the death of Hakham Isaac Aboab de Fonseca in 1693. In one passage the names of Isaac Uziel and Saul Levi Mortera appear followed by the phrase "of blessed memory," indicating their death, while Aboab's did not. Furthermore, the putative author Moseh Sasportas refers to his father Jacob as an old man at the time of writing. Without too much exegetical strain but without making too firm a commitment, responsum 60 appears to date from the 168 os or early 1690 s.

The responsum is long, occupying roughly three folio pages of Ohel Ya'akov. In it Moseh Saportas recounts a rebellion of the students against his father who had served as their teacher. Unlike many of the other responsa in Ohel Ya'akov, which name an addressee and which attempt to resolve a specific and relatively delineated legal problem, responsum number 60 reads as if it is a report of an incident rather than a letter written to a given individual. At times, the rebellious students seem to be the addressee, at others, Jacob Sasportas, and at still others, no one in particular. In terms of the legal issue: the most recurring legal problem appears to be one of issuing instruction before one's teacher. This legal matter takes on two manifestations, the first (and the ostensible cause for the writing of the responsum) pertains to the students flouting the authority of Jacob Sasportas in the Ets Haim yeshiva; the second to Moseh Sasportas's ability to write such a responsum in the presence of his father. In a sense, the second problem was simply one of rhetoric. But the rhetorical choices were significant. Responum 61 in Ohel Ya'akov, which immediately follows, is actually a coda to this one, in which Jacob Sasportas applauded his son's efforts on his own behalf. ${ }^{14}$

The description of a student rebellion against Sasportas in Ets Haim bears a number of striking parallels to Sasportas's own account of Sabbatianism in Zizath Novel Zvi. The two central issues broached in the responsumSasportas's authority as a rabbi and the honor of his position and his person-were veritable leitmotifs within Zizath Novel Zvi. In fact, one might

\footnotetext{
12 For his commentary on the Mishnah and his hopes for its appearance in print, see Zizath Novel Zvi, 229.

13 Sasportas, Ohel Ya'akov, 65a-68a.

14 Ibid., 68a-68b.
} 
even go so far as to say that Sabbatianism as understood by Sasportas was by and large a crisis of authority at the level of the Jewish community and an affront on his own personal honor at the level of his own experience. Thus, to a certain degree, what happened in the Ets Haim yeshiva in the 168 os or 169os was narrated in terms that were strikingly similar to the way Sasportas described Sabbatianism in the 1660 os.

Much of the language used in this responsum echoed various passages in Zizath Novel Zvi. Thus in the responsum, Moseh Sasportas lamented the reversal of social hierarchies: "The order has been reversed and those on top are now on the bottom, and those on the bottom are now on top."15

At the height of the Sabbatian frenzy, Aaron Zarfati wrote to Sasportas: "If you were here [in Amsterdam] you would see a world turned upside down."16 In his own description of life in Hamburg at the same time, Sasportas recounted, "And the rabble have overcome their leaders, and there is no one to respond to them."17 Just as the reversal of traditional social hierarchies in the period of Sabbatian enthusiasm had led Sasportas to put pen to paper and embark on an epistolary campaign, the unbecoming impudence of the students in Ets Haim had compelled Moseh Sasportas to defend his father's honor.

Much of the discussion in this responsum concerned respect for rabbinic authority. In discussing the story, Moseh Sasportas wrote: "Let someone look at this with his mind's eye, at even the most superficial level, what punishment is given to those who are arrogant before their teachers."18 In Zizath Novel Zvi, Sasportas had responded in a very similar style to one of Nathan of Gaza's letters: "Let someone look with the fine eye of Jewishness at the words of this denier." 19

Furthermore, in another passage toward the end of the responsum, Moseh Sasportas dwelled at relative length on another affront to his father's honor. He writes:

As if it were not enough what they had done in the study house with their instruction, denigration and seizure of authority in front of the rabbi, but even in the synagogue, in public, they sought to malign his honor. When he rose to the lectern and was summoned to the Torah, the members of the study house would usually stand in his honor for the duration

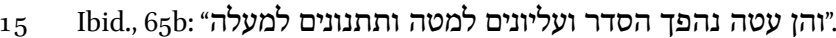

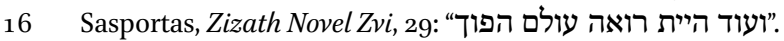

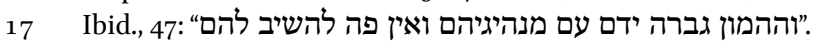

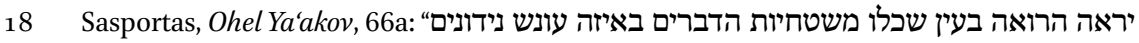
זהותם אשר בפני הרב מתיהרים"

19 Sasportas, Zizath Novel Zvi, 201: "יראה הרואה בעין יפה של היהדות בדברי הכופר הזיר." 
of the time he read from the Torah scroll. Although by law they were not required to do so, apart for the moment when he passed in front of them, nonetheless, since the founding of this congregation, the days of Rabbi Isaac Uziel and Rabbi Saul Levi Mortera, of blessed memory, and Rabbi Isaac Aboab, all the students behaved modestly before their teachers and stood as long as they were at the lectern as a sign of respect and honor. And they used to do this for my father as well. But this time, they refused, since they had determined that they were greater than their colleagues and they no longer needed a rabbi. [Since] he was no longer their rabbi, they sat in their places while some of their colleagues stood. ${ }^{20}$

The rebellion was partial rather than total. Not all of the students openly flaunted Sasportas's authority. Some continued to stand out of respect for their teacher, while others sat in defiance. Moreover, the rebellion had to do with the curriculum and a sentiment among some of the students that they no longer had any need for Sasportas's instruction. If this incident took place in the $1680 \mathrm{~s}$ or 169os, it hardly comes as a surprise that a group of students, not always the most staid stratum within society, found the teaching of an irascible old man somewhat cumbersome.

Moseh Sasportas drew a clear distinction between the study house, the beit midrash, and the synagogue, the beit ha-knesset. There can be little doubt that Ets Haim yeshiva was an elitist institution meant to provide in-depth training for a number of outstanding students. Admission was difficult in the seventeenth century and remained competitive well into the eighteenth century. ${ }^{21}$ Instruction was rigorous. One of the remarkable facts about the Portuguese Jews of Amsterdam was their ability to found and maintain a yeshiva that within a few generations could produce its own rabbinic elite, although this in no way stemmed the flow of rabbis from elsewhere who served the same

20 Sasportas, Ohel Ya'akov, 67b:

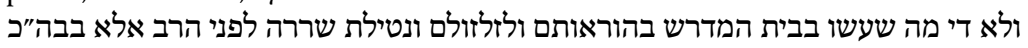

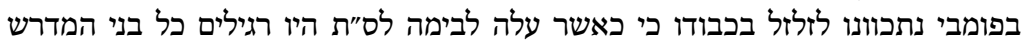

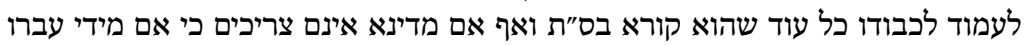

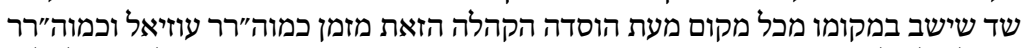

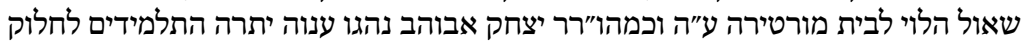

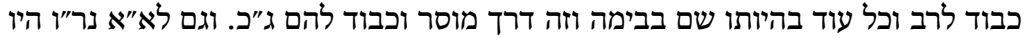

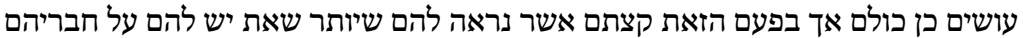

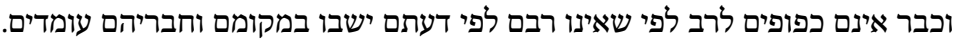

21 Gerard Nahon, "R. Rafael b. Eleazar Meldola in Bayonne, 1728-1741," [Hebrew] in Lo Yasur Shevet mi-Yehuda: Hanhaga, Rabanut, ve-Kehila be-Toledot Yisrael Mehkarim Mugashim leProfessor Simon Schwarzfuchs, ed. Joseph R. Hacker and Yaron Harel (Jerusalem: Mossad Bialik, 2011), 279-80. 
community. But the yeshiva was its own world and relatively closed off from the rest of the community. To a certain extent, what happened in the study hall stayed in the study hall. The synagogue, however, was an altogether different story. Almost by its very nature, the synagogue was a public institution. Gentiles came to visit the synagogue; deals were made in its courtyard; the community came together as a community in the synagogue. ${ }^{22}$ Even though the Ets Haim yeshiva of the 168 os and 16 gos was in the same physical complex as the Esnoga, the one was a private, elitist place of instruction, the other was a raucous, boisterous display of power and wealth. Thus when the yeshiva students took the liberty of breaking publicly with established custom and sitting while their teacher was called to the Torah in the synagogue, this was an affront of an altogether different order from their contempt for Sasportas's instruction in the halls of the study house. It was a public humiliation of a kind which neither Sasportas nor his family could suffer in silence.

Moreover, this distinction between the synagogue and the study house had already appeared within Zizath Novel Zvi. In the aforementioned letter by Aaron Zarfati to Sasportas that described the world turned upside down, Zarfati wrote, "If you could see with your own eyes, you would certainly say it was the hand of God. All day and all night, they fill the synagogue as if it were a day of atonement to God; ten thousand florins were pledged on the holy Sabbath; several benches were added to our yeshiva on that very day. Furthermore, you would see a world turned upside down." 23

Zarfati took care to distinguish between the messianic response of the synagogue and the study house. He separated the synagogue, a space where all members of the community convened for worship, from the study house, an academy where the learned elites studied Talmud in seclusion. The synagogue was theoretically open to all Jewish men; the study house was reserved for the elite who studied in splendid isolation. Excitement about the Messiah seems to have cut across all sectors of the Jewish community in such a dramatic fashion that the synagogue and the study house were alike transformed. Following the explosion of messianic excitement, both witnessed a dramatic increase in their respective constituencies. In order to impress upon Sasportas the radical break represented by Sabbatianism, Zarfati emphasized that it cut across two opposing institutions, the study house and the synagogue. So too Moseh

22 Yosef Kaplan, "Order and Discipline in the Portuguese Synagogue of Amsterdam," in Jewish Studies and the European Academic World, ed. Albert van der Heide and Irene E. Zwiep (Paris and Louvain: Peeters, 2005), 1-14.

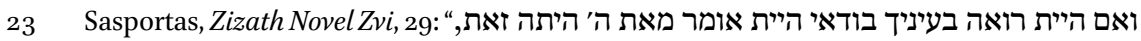

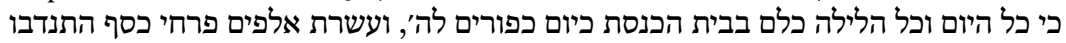
ביום שבת קדש וכמה ספסלים הלם הוסיפו בישיבתנס כיום כפורים כמו ביום ועשרת ועוד היית רואה עולם כסף הפוך." 
Sasportas, in emphasizing the affront to his father's honor, concluded the responsum with an account of the disrespect to Jacob Sasportas in public, meaning the synagogue, and not only in the semi-public sphere of the study house.

Responsum 6o thus reads somewhat like one of Sasportas's own letters included in Zizath Novel Zvi. In terms of language, many of the very same phrases used in Sasportas's letters reappeared in this responsum; the density of allusions that characterized Saportas's own writing repeated itself; and the acerbic criticism, the penchant and almost relish for intellectual combat that characterized Zizath Novel Zvi held true for the depiction of the rebellious students. Equally significant was the overlap in terms of content. Fear of social chaos and concern for his own honor were two of the central themes throughout Sasportas's account of Sabbatianism.

If this responsum reads as if it were right out of Zizath Novel Zvi, I suggest that Jacob Sasportas, rather than Moseh Sasportas, was its actual author. Two additional pieces of information appear to support this suggestion. The first has to do with style and the second with material evidence. In terms of style, Sasportas had adopted this technique of ventriloquizing himself in at least one instance. Toward the end of Zizath Novel Zvi, a full two years after Sabbetai Zevi's conversion, Sasportas had learned that the Jews of several communities in North Africa had continued to celebrate the ninth of Av as a holiday in Sabbatian style. He wrote a long letter condemning their practice and put the letter in the name of one of his own fictitious students and repeatedly discussed himself in the third person. Sasportas was thus fully capable of hiding behind someone else or using the voice of one of his own subordinates in the service of polemic. ${ }^{24}$

At the level of material evidence, a number of factors point to Jacob as the author. Ohel Yaakov survives in a single manuscript now at the Mendel Gottesman Library of Yeshiva University in New York. ${ }^{25}$ This manuscript shows many of the telltale signs of having been used as the copy text for the 1737 printing of the first and only edition. Many of the pages have the marks of a corrector; paragraph breaks correlate between the manuscript and printed edition; when the printed text includes a note that the responsum ends abruptly, the text in the manuscript ends abruptly as well. In his preface to Ohel Ya'akov Abraham Sasportas indicates that the manuscript used by the printer was in Sasportas's own hand, a handwriting that he conceded was appallingly difficult to read. ${ }^{26}$ Responsum number 60 is in the same semi-cursive hand as the rest

24 Sasportas, Zizath Novel Zvi, 358.

25 YU MS 1251, vol. 2.

26 Sasportas, Ohel Ya'akov, $4 \mathrm{~b}$. 
of the manuscript and as the other known samples of Sasportas's handwriting. Furthermore, there is complete continuity between responsum 60 and responsum 61 , which is acknowledged to have been written by Jacob. ${ }^{27}$ It seems that Sasportas himself rather than Moseh wrote it.

There are a number of possible objections to this hypothesis. First, Moseh may have had awful handwriting like his father. This is certainly possible, but given that no manuscripts written by Moseh appear to have survived, it is impossible to know; one might add that Sasportas's one son in whose hand Hebrew manuscripts survive, Isaac, wrote in a perfectly legible script. ${ }^{28}$ Second, the YU manuscript may be a copy of the printed book, rather than vice versa. A companion manuscript to the one of Ohel Ya'akov that contained Sasportas's notes for Zizath Novel Zvi (and that served as one of the most important sources for Tishby's edition) survives. ${ }^{29}$ It seems that these two manuscripts contained the bulk of Sasportas's writings and were preserved by his family after his death. Abraham Sasportas hired David Meldola as he reported in his preface to cull from these notebooks a collection of his legal responsa that appeared as Ohel Ya'akov and a selection of letters on Sabbetai Zevi that appeared as an appendix to the same volume entitled Kitzur Zizath Novel Zvi. In short, the manuscript that contains Ohel Ya'akov appears to have been the source for the printed text rather than vice-versa.

Does it make a difference if Sasportas or his son Moseh wrote the account of the student rebellion contained in responsum 6o? Sasportas was an old man at the time of his contest with the students of Ets Haim. About this, there is no dispute. He may have ventriloquized himself through Moseh because it would have been conduct unbecoming for someone of his age and stature to defend himself in public. But the offense by the students was so great, particularly once it had spilled out into the synagogue that some form of defense was absolutely necessary. And who better to defend the honor of a maligned rabbinic luminary than that luminary's son?

\section{Bibliography}

Azulai, Hayim Joseph David. Sefer Ma'gal Tov ha-Shalem. Edited by Aron Freimann. Jerusalem: Mekize Nirdamim, 1934.

27 YU MS 1251, vol. 2. 107a-112a.

28 See his eulogy for his father in Amsterdam, Ets Haim, MS $47 \mathrm{C}_{36}$, 4a-1ob.

29 YU MS 1251, vol. 1. 
Franco Mendes, David. Memorias do estabelecimento e progresso dos Judeos Portuguezes e Espanhoes nesta famosa citade de Amsterdam. Edited by L. Fuks and R.G. FuksMansfeld. Special Issue of Studia Rosenthaliana 9, 1975.

Goldish, Matt. "Hakham Jacob Sasportas and the Former Conversos." Studia Rosenthaliana 44 (2012): 149-72.

Havlin, S.Z. "On the History of the Talmudic Academies in Jerusalem and Their Scholars at the End of the Seventeenth and Early Eighteenth Centuries." [Hebrew] Shalem 2 (1976): 113-92.

Kaplan, Yosef. "Order and Discipline in the Portuguese Synagogue of Amsterdam." In Jewish Studies and the European Academic World. Edited by Albert van der Heide and Irene E. Zwiep, 1-14. Paris and Louvain: Peeters, 2005.

Kaplan, Yosef. "The Social Functions of the Herem." In An Alternative Path to Modernity: The Sephardi Diaspora in Western Europe. Pp. 108-42. Leiden: Brill, 2000.

Levie Bernfeld, Tirtsah. Poverty and Welfare among the Portuguese Jews in Early Modern Amsterdam. Portland, OR: The Littman Library of Jewish Civilization.

Nahon, Gerard. "R. Rafael b. Eleazar Meldola in Bayonne, 1728-1741." [Hebrew] In Lo Yasur Sshevet mi-Yehuda: Hanhaga, Rabanut, ve-Kehila beToledot Yisrael Mehkarim Mugashim le-Professor Simon Schwarzfuchs. Edited by Joseph R. Hacker and Yaron Harel, 271-99. Jerusalem: Mossad Bialik, 2011.

Sasportas, Isaac. Writings. Amsterdam, Ets Haim Library, MS 47 C 36.

Sasportas, Jacob. Ohel Ya'akov. Edited by David Meldola. Hertz Levi Rofe: Amsterdam, 1737 .

Sasportas, Jacob. Writings. New York, Yeshiva University, Mendel Gottesman Library, MS 1251, vols. 1-2.

Sasportas, Jacob. Zizath Novel Zvi. Edited by Isaiah Tishby. Jerusalem: Mossad Bialik, 1954.

Tishby, Isaiah. "Letters by Rabbi Jacob Sasportas against the Parnassim of Livorno from 1681. [Hebrew]) Kovets al Yad 4 (1946): 143-6o.

Tishby, Isaiah. "New Information on the 'Converso' Community in London according to the Letters of Sasportas from 1664/1665." [Hebrew] In Galut Ahar Golah: Mehkarim be-Toldot Am Yisrael Mugashim le-Professor Haim Beinart li-Melot Lo Shivim Shanah. Edited by Aharon Mirsky et. al, 470-96. Jerusalem: Ben Zvi Institute, 1988. 